\title{
Oral and maxillofacial rehabilitation of a patient suffering from intraosseous adenoid cystic carcinoma
}

\author{
Reabilitação bucomaxilofacial de paciente portador de carcinoma adenóide cístico intraósseo
}

\author{
Janine WAECHTER ${ }^{1}$ \\ Cristina Braga XAVIER ${ }^{1}$ \\ Gislene CORRÊA \\ Eduardo de Freitas GOMES² \\ Romeu Belon FERNANDES FILHO3
}

\begin{abstract}
Treatment of cancers of the head and neck may provoke sequelae that affect the quality of life of patients during and after treatment. Mouthsinus communication resulting from partial or total surgical resection of the palate leads to the patient experiencing dysphagia, dysphonia and trismus, which can lead to social isolation of the individual. As a result, the work of the dental surgeon, together with the multidisciplinary team caring for cancer patients, is fundamental and can help with the diagnosis, assist in the management of chemotherapy and radiotherapy complications and enable postsurgical rehabilitation. The present study reports the case of a patient with adenoid cystic carcinoma in the right maxilla, who underwent a partial maxillectomy, the resulting sequela being mouth-sinus communication. The dental treatment was performed at the Hospital of the Federal University of Pelotas preoperatively, during and after treatment. At this time the patient is rehabilitated with an obturator prosthesis and is being monitored by the dental team and the head and neck surgeon.
\end{abstract}

Indexing terms: Carcinoma, adenoid cystic. Maxillofacial prosthesis. Head and neck neoplasms.

\section{RESUMO}

O tratamento das neoplasias em região de cabeça e pescoço pode deixar sequelas que afetam a qualidade de vida do paciente durante e após o tratamento. A comunicação buconasosinusal decorrente da ressecção cirúrgica parcial ou total do palato traz ao paciente alterações na função mastigatória, estética, fonética e de deglutição o que pode levar a um isolamento social do indivíduo. Em vista disso, a atuação do cirurgião dentista junto à equipe multiprofissional de atendimento ao paciente oncológico se faz fundamental, podendo contribuir no diagnóstico, auxiliar no manejo de complicações do tratamento quimioterápico/radioterápico, e na reabilitação bucomaxilofacial, sendo esta uma alternativa para melhorar a qualidade de vida do paciente, pois visa restabelecer as funções alteradas em decorrência do procedimento cirúrgico. O presente estudo relata o caso de uma paciente portadora de carcinoma adenóide cístico na maxila submetida à maxilectomia parcial, deixando como seqüela a comunicação buconasosinusal. O acompanhamento odontológico foi realizado no Hospital Escola da Universidade Federal de Pelotas no pré-operatório, durante e após o tratamento. No momento a paciente está reabilitada com uma prótese obturadora em acompanhamento pela equipe de odontologia e pelo cirurgião de cabeça e pescoço.

Termos de indexação: Carcinoma adenoide cístico. Prótese maxilofacial. Neoplasias de cabeça e pescoço.

\section{INTRODUCTION}

Cancer is one of the main causes of death throughout the world. In Brazil, estimates for 2015 point to the occurrence of approximately 576,000 new cases of cancer, including cases of non-melanoma skin cancer (182,000 new cases). New cases of cancer of the oral cavity are estimated at $11,280^{1}$. Salivary gland tumors are not common, amounting to around $1 \%$ of tumors in the entire human body. Adenoid Cystic Carcinoma (ACC) is one of the more common salivary gland tumors, responsible for approximately $6-10 \%$ of all salivary carcinomas ${ }^{2}$, generally affecting the smaller salivary glands in the palate, the parotid and submandibular ${ }^{3}$. It occurs most frequently in the fifth decade of life and usually in women. Described for the first time in 1859 by Theodor Billroth as "Cylindrome", it was designated by Ewing, in 1954, as $\mathrm{ACC}^{4}$. As of the present time, three histological growth patterns have been described, depending on the predominance of the histological pattern; solid variants are lesions with a high degree of malignance with reported recurrence rates of up to $100 \%$, compared with $50-80 \%$ for the tubular and

\footnotetext{
${ }^{1}$ Universidade Federal de Pelotas, Faculdade de Odontologia, Departamento de Cirurgia, Traumatologia e Prótese Buco-Maxilo-Faciais. Rua Gonçalves Chaves, 457, 96015-560, Centro, Pelotas, RS, Brasil. Correspondência para / Correspondence to: CB XAVIER. E-mail: <crisbuco@yahoo.com.br>.

2 Hospital Escola da Universidade Federal de Pelotas, Departamento de Cirurgia de Cabeça e Pescoço. Pelotas, RS, Brasil.

Sociedade Brasileira de Cirurgia de Cabeça e Pescoço. Pelotas, RS, Brasil.

3 Hospital Escola da Universidade Federal de Pelotas, Residência Integrada Multiprofissional em Saúde. Pelotas, RS, Brasil.
} 
cribriform variants ${ }^{2}$. Intraosseous occurrences of malignant salivary gland tumors are rare, with mucoepidermoid carcinoma being the most common, followed by ACC, which could complicate or even delay correct diagnosis. Various theories have been proposed to explain the origin of these neoplasms, including: a) tissue remains of ectopic salivary glands, b) neoplastic transformation of odontogenic epithelial cysts, and c) the neoplastic transformation of the sinus epithelium ${ }^{5}$.

The predominant mode of treatment is surgical resection, with en bloc or radical excision, guaranteeing ample margins of safety, and it may be combined with radiotherapy. As a consequence of the surgical treatment, we have large local defects which may substantially affect the patient's quality of life. To minimize the sequelae of treatment and mitigate the loss of quality of life, oral and maxillofacial rehabilitation, with obturator prostheses in the maxillae, has been widely used. According to Kusterer et al. ${ }^{6}$, this rehabilitation aims to restore the functions of chewing, voicing, swallowing and esthetics, important for reintegrating patients into society, improving their selfesteem and guaranteeing them a modicum of comfort to carry out their daily routines ${ }^{6-7}$.

The aim of the present report, through the description of procedures and techniques, is to demonstrate the importance of integrated healthcare and individual treatment, according to the needs of each patient ${ }^{8}$, by way of a medical/dental coming-together to diagnose and treat the disease, as well as in the rehabilitation of the sequelae.

\section{CASE REPORT}

This study is a report of a descriptive case in which we address the procedures for fabricating the complete obturator prosthesis of female patient N.S.L. aged 55, sufferer of adenoidal cystic carcinoma in the maxilla.

The study was conducted in compliance with the Brazilian National Health Council Resolution 196/96. The design was approved by the Ethics Committee at the UFPel University Hospital in Pelotas, in the Brazilian state of Rio Grande do Sul, under opinion no. 865.969.

In November 2013, a female Caucasian patient, aged 55, employed as a waitress, with no habits or comorbidities, came to the Oncology sector of the University Hospital in Pelotas, Rio Grande do Sul, with a referral for the treatment of a malignant tumor located in the right nostril. The lesion, which had been found by chance, was identified as ACC with a tubular and cribriform pattern, following an anatomical-pathological examination of the surgical specimen, confirmed by immunohistochemistry $(\mathrm{IHC})$ at the time of the resection of the mucous retention cyst in the right maxillary sinus, carried out the previous month by the ENT specialist.

Referred for a dental evaluation, the patient reported painful symptoms deep in the right upper anterior sulcus, coinciding with the subsequent appearance of a hyperplastic-looking erythematous lesion in the 11 to 13 apical region, though she could not confirm how long it had been developing. The patient used a well-fitting complete upper denture that did not cause any local trauma. A panoramic $x$-ray was taken (Figure 1) to evaluate the lower dentition and other facial bone structures, there being a perceptible, well-delimited radiolucent lesion about $1.5 \mathrm{~cm}$ in diameter, on the floor of the nostril to the right of the midline.

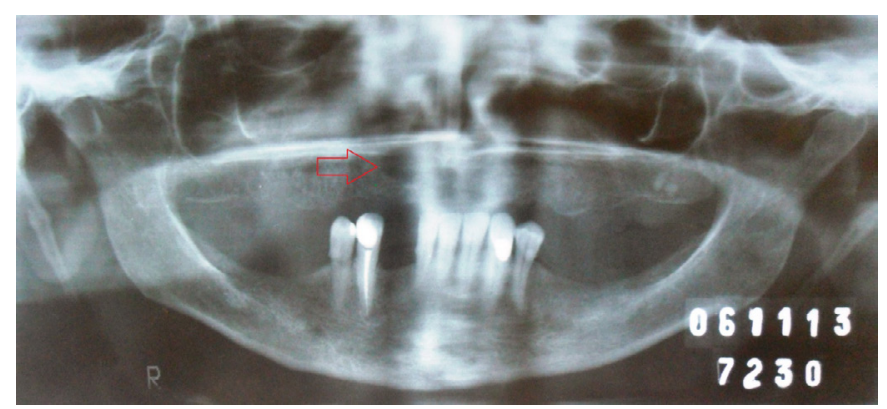

Figure 1. Panoramic x-ray, the arrow identifying the well-delimited radiolucent lesion next to the floor of the right nostril, measuring approximately 1.5 $\mathrm{cm}$ at its largest diameter.

In January 2014, the patient underwent surgery to remove the lesion, performed by a head and neck surgeon The procedure damaged the lateral wall of the maxillary sinus, the floor of the nasal cavity and the premaxilla on the right, together with the hard palate as far as the transition with the soft palate. Adjuvant treatment with radiotherapy was recommended. One week after the operation, the patient was experiencing slightly painful symptoms in the operated region, the social impact of the mouth-sinus communication being the major cause for complaint. The destabilization of the complete upper denture produced anxiety and significant discomfort. As a result, direct rebasing was carried out using resilient, selfpolymerizing acrylic resin (Soft Confort, Dencril, SP, Brazil) thus improving the fit and consequently the possibility 
of eating more satisfactorily (Figure 2). The patient was informed about the consequences of radiotherapy for the mouth, as well as the importance of oral hygiene and denture care. The treatment plan decided upon together with the patient involved extracting the right central incisor, due to grade II mobility and an accentuated loss of bone insertion, scraping, smoothing and polishing of the remaining teeth, the required restorations, fabrication of a silicone plate in the lower dentition for the daily application of $1.1 \%$ neutral fluoride gel with the aim of avoiding radiation-induced caries and the fabrication of new dentures once radiotherapy had finished.

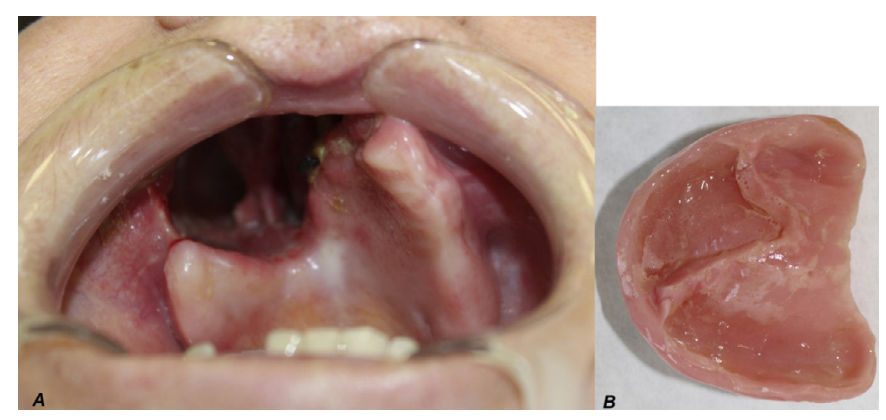

Figure 2. One week after surgery. A) mouth-sinus communication. B) Complete upper denture rebased with resilient self-polymerizing acrylic resin.

After two months, a new rebasing of the complete upper denture was carried out. Three months after surgery, the patient has a stress-bearing area in the erythematous palate, clinically consistent with a diagnosis of chronic atrophic candidiasis (CAC) and acknowledges not removing the complete upper denture during the night, alleging discomfort. Daktarin oral gel was prescribed for the treatment. The patient only began radiotherapy in the Radiotherapy and Oncology Center at the Santa Casa hospital in Pelotas (CERON) 4 months after the surgical procedure due to the high demand for the service. She was exposed to a dose of $50 \mathrm{~Gy}$ distributed in 25 fractions, with a $6 \mathrm{MV}$ photon beam, through three fields (anteroposterior and the two sides). Reaction to treatment included epithelitis, hyposalivation and grade I mucositis, as per the World Health Organization classification. Six months after surgery, the fabrication begins of new dentures, a complete upper obturator prosthesis and a lower removable partial denture (RPD), observing the following timetable:

\section{Chart 1.}

Appointment 1 Molding of the arches with alginate (Cavex ColorChange, The Dental Advisor, The Netherlands) in order to obtain study molds.

Laboratory stage Fabrication of the individual upper impression tray and outline for planning the lower RPD.

Appointment 2 Fabrication of the recesses for the RPD and working model of the lower arch with alginate, and working model of upper arch with polyether (Impregnum Soft; 3M, SC, Brazil) (Figure 3).

Laboratory stage Fabrication of the metal frame and upper joining plate.

Appointment 3 Frame fitting test and recording of intermaxillary relation, choice of tooth color, decided in conjunction with the patient, using a color scale (Trilux, VIPI Dent Plus, SP, Brazil).

Laboratory stage Assembling the teeth.

Appointment 4 Functional and esthetic test.

Laboratory stage Acrylization (Figure 4)

Appointment 5 Installing the dentures (Figure 5)

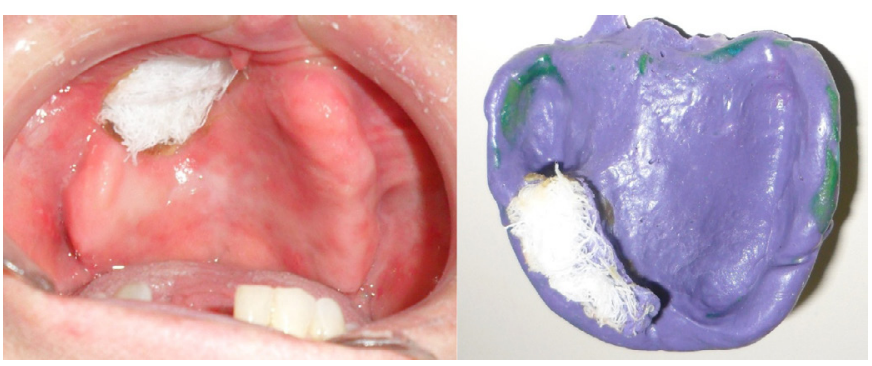

Figure 3. Making the working model of the upper arch with individual impression tray and polyether (Impregnum Soft; 3M, SC, Brazil). The mouth-sinus communication is filled with gauze coated in Vaseline for the greater comfort of the patient and to avoid the draining of the molding material.

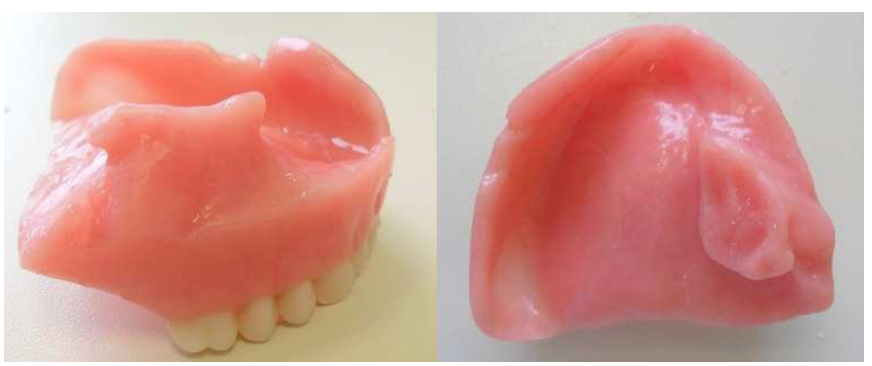

Figure 4. Complete upper obturator denture, extension for better retention and sealing of the mouth-sinus communication.

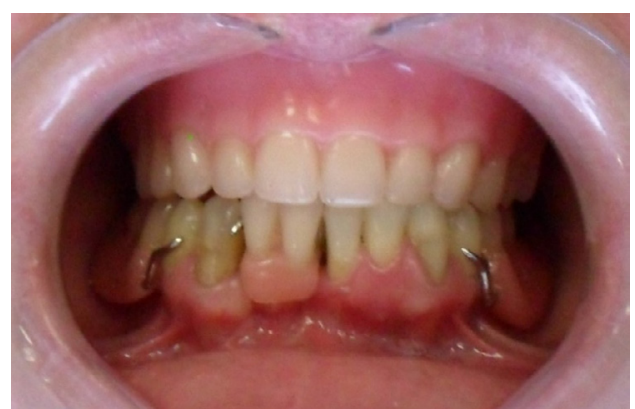

Figure 5. Patient nine months after surgery, installation of complete upper obturator and lower removable partial dentures. 
After installing the dentures, reassessments and readjustments were carried out on a weekly basis until they were properly contoured to the specifics of the case. Eighteen months after surgery, the patient does not have enlarged lymphatic ganglion, the edges of the lesion have healed well, without signs of recurrence of the tumor, and has adapted to the use of dentures that have restored chewing, speech, swallowing and esthetic function, thereby improving her quality of life.

\section{DISCUSSION}

Although the frequency of malignant tumors in the minor salivary gland of the intraosseous ACC type may be rare, particularly in the maxilla, it should be included in the differential diagnosis of expansive bone lesions. The advocated treatment for ACC is surgical resection of the lesion followed by radiotherapy. The removal of the lesion should be carried out with margins free of disease, and ganglion emptying should not be carried out in cases of clinically negative neck, it being rare for it to affect these structures through the metastasis of tumors at the very top of the mouth ${ }^{9}$. Indications for radiotherapy as a supplementary treatment in cases of cancer of the salivary gland include: a) presence of tumor in the bone; $b$ ) aggressive histological type; c) damaged surgical margins.

The institution of a quick treatment and a long period of monitoring, of around 10 years, is recommended in these cases, as no treatment method completely eliminated the possibility of an intraosseous ACC relapse (5). Even where adequate treatment is performed, recurrence is not infrequent, being as much as $42 \%{ }^{10}$. Moreover, these tumors have a great propensity for distant metastasis, most commonly the lungs, and nerve invasion, and may afflict the base of the skull. These manifestations of the disease can occur several years after initial treatment due to its indolent behavior which allows patients to enjoy a long period of survival, with multiple recurrences that can lead to death from the disease. Five-year survival rates are around $30 \%$. Although surgical removal is the best treatment option, there is consequential harm for the patient. In order to reduce this, dental monitoring is required, reconstituting shape and basic functions ${ }^{11}$.

Rehabilitation with an obturator prosthesis is often used as it is a low-cost, non-invasive procedure which, when removed, permits a clinical examination of the site, which makes possible the early discovery of a potential neoplasm recurrence ${ }^{12-13}$. Rehabilitating maxillary defects in patients who are either partly or fully edentulous can be a challenge ${ }^{14}$. With smaller defects, the obturator prosthesis succeeds in offsetting surgical loss together with the dental rehabilitation, with satisfactory esthetic and functional results. However, when faced with more extensive defects, problems such as lack of support, retention and stability of the prosthesis are often present due to the loss of palatal bone, teeth and surrounding supporting tissue ${ }^{15}$. As a result, some techniques have been reported in the literature in respect of the development of the hollow-bulb obturator, which may be open or closed, and this reduces the weight of the prosthesis, making it more comfortable and effective for the patient ${ }^{16-17}$. The use of the closed hollow obturator has the advantage of possessing a configuration that is easier to clean, which would make it easier for patients with motor or visual difficulties ${ }^{14}$. In cases where the hollow obturator bulb is chosen, it is important to do the job without multiple reentry and smoothly, thereby facilitating cleaning. Thus, for the fabrication of the prosthesis to be successful, there should be an interaction between adequate clinical and laboratory techniques. This will facilitate insertion and removal of the prosthesis, good hygiene, adding up to a better quality of life for the patient ${ }^{13}$.

Rehabilitation with an obturator prosthesis restores the missing structures and acts as a barrier, preventing communication between the various cavities, improving esthetics, phonetics and masticatory function. Patients with maxillofacial defects face numerous problems related to quality of life arising from sequelae in function, speech, appearance, dry mouth, difficulty in opening the mouth ${ }^{18-19}$. Rehabilitation with an obturator prosthesis demonstrated better quality of life of patients with head or neck cancer ${ }^{20-21}$. A retrospective study indicated that chewing after reconstruction with an obturator prosthesis is comparable with chewing with complete dentures and the size of the defect did not have a significant influence on the functional outcome ${ }^{22}$.

Difficulties experienced by patients with maxillary defects resulting from surgery, traumas or congenital malformations are reduced if a team approach is adopted. Professionals in the area of psychology, speech therapy, oncology, head and neck surgery, nutrition, ENT, dental surgery, physiotherapy, among others, must be part of the multidisciplinary team ${ }^{23}$. The specialists must exercise care in applying their skills and experience in all phases of treatment and keep the patient under regular supervision ${ }^{24}$.

The prosthetic rehabilitation fulfilled its purpose, 
providing patient well-being, offering improvements in speech, chewing and swallowing. Accordingly, it made it possible for the patient to reintegrate into society. Oral and maxillofacial rehabilitation procedures have been described very little in the literature, which could make it difficult for the dental surgeon to carry out the work when faced with a rehabilitation of this type. Moreover, in the report of the case described, the participation of the dental surgeon before, during and after oncological treatment of the neoplasms of the maxillofacial complex demonstrates the importance of having professionals forming a multidisciplinary team.

\section{CONCLUSION}

Dentistry, in combination with other health-related areas, in the multidisciplinary care of oncology patients, makes a significant contribution to minimizing the

\section{REFERENCES}

1. Instituto Nacional de Câncer - INCA. Câncer [citado 2014 Dez 10]. Disponível em: <http://www.inca.gov.br/estimativa/2014/ index.asp? $\mid \mathrm{D}=2>$.

2. Desphande PS, Chintamaneni RL, Sujanamulk B, Prabhat MP, Gummadapu S. Intraosseous adenoid cystic carcinoma of maxilla: A rare case report. Contemp Clin Dent. 2013;4(2):23942. doi: 10.4103/0976-237X.114872

3. Neville BW, Damm DD, Allen CM, Bouquot JE. Patologia oral e maxilofacial. 3a ed. Rio de Janeiro: Elsevier; 2009.

4. Capodiferro S, Scully C, Macaita MG, Lacaita MG, Lo Muzio L, Favia G. Bilateral intraosseous adenoid cystic carcinoma of the mandible: report of a case with lung metastases at first clinical presentation. Oral Disease. 2005;11(2):109-12.

5. Martinez-Madrigal F, Pineda-Daboin K, Casiraghi O, Luna MA Salivary Gland Tumors of the Mandible. Ann Diagn Pathol. 2000 Dec;4(6):347-53. doi: 10.1053/adpa.2000.19395

6. Kusterer EFL, Paraguassú GM, Silva VSM, Sarmento VA. Reabilitação com obturador maxilar após cirurgia oncológica: relato de casos. Rev Cir Traumatol Buco-Maxilo-Fac. 2012;12(4):9-16.

7. Duke RL, Campbell BH, Indresano AT, Eaton DJ, Marbella AM, Myers KB, et al. Dental status and quality of life in long-term head and neck cancer survivors. Laryngoscope. 2005 Apr;115(4):67883. doi: 10.1097/01.mlg.0000161354.28073.bc

8. Hofmann TK. Systemic therapy strategies for head-neck carcinomas: current topics in otorhinolaryngology. GMS Curr Top Otorhinolaryngol Head Neck Surg. 2012; 11: Doc03. doi: 10.3205/cto000085

9. Pushpanjali M, Sujata DN, Subramanyam SB, Jyothsna M. Adenoid cystic carcinoma: an unusual presentation. J sequelae caused by disease or treatment. The maxillofacial denture permits the rehabilitation of patients with defects caused by the surgical removal of neoplasms from the maxillofacial complex. With prosthetic rehabilitation, it is possible to provide comfort, functionality and abilities such as swallowing and speech in a satisfactory manner, improving quality of life and the reintegration of these patients into the biopsychosocial world.

\section{Collaborators}

J WAECHTER, case assistant and manuscript author. CB XAVIER, guidance in the preparation of case report. G CORREAA, customer service and collaboration in the preparation of case report. EF GOMES, oncologic surgery and collaboration in preparing. RB FERNANDES FILHO, responsible for some images.

Oral Maxillofac Pathol. 2014 May-Aug; 18(2):286-90. doi: 10.4103/0973-029X.140796

10. Parise $\mathrm{O}$, Kowalski LP, Lehn C. Câncer de cabeça e pescoço: diagnóstico e tratamento. São Paulo: Âmbito Editores; 2008.

11. Tsukahara K, Nakamura K, Motohashi R, Sato H. Two cases of small cell cancer of the maxillary sinus treated with cisplatin plus irinotecan and radiotherapy. Case Rep Otolaryngol. 2013;2013:893638. doi: 10.1155/2013/893638

12. Kar S, Tripathi A. Treatment outcome with delayed maxillary obturator prosthesis: case series of four patients. J Prosthodont. 2016 Feb;25(2):174-7. doi: 10.1111/jopr.12275

13. Goiato MC, dos Santos DM, Magri FM, Rahal V, Andreotti AM, Moreno A, et al. Rehabilitation of maxillary cleft with hybrid obturator prosthesis. J Craniofac Surg. 2013;24(5):517-21. doi: 10.1097/SCS.0b013e3182a23754

14. Krishna CH, Babu JK, Fathima T, Reddy GV. Fabrication of a hollow bulb prosthesis for the rehabilitation of an acquired total maxillectomy defect. BMJ Case Rep. 2014;2014: bcr2013201400. 26. doi: 10.1136/bcr-2013-201400

15. Neves ACC, Murgo DA, Campoy CD, Orlando ED, Côas VR. Prótese facial combinada. RGO, Rev Gaúch Odontol. 2005;53(1):81-4.

16. Choudhury M, Shanmuganathan N, Padmanabhan TV, Swarup S, Grover M, Arumugam M. Rehabilitation of post surgical maxillectomy defects using interim obturators-a case series. Indian J Surg Oncol. 2014;5(4):315-20. doi: 10.1007/s13193014-0361-0

17. Vojvodic D, Kranjcic J. A two-step (altered cast) impression technique in the prosthetic rehabilitation of a patient after a maxillectomy: a clinical report. J Prosthet Dent. 2013;110(3):22831. doi: 10.1016/S0022-3913(13)60363-7

18. Hertrampf K, Wenz HJ, Lehmann KM, Lorenz W, Koller M. Quality 
of life of patients with maxillofacial defects after treatment for malignancy. Int J Prosthodont. 2004;17(6):657-65.

19. Chigurupati R, Aloor N, Salas R, Schmidt BL. Quality of life after maxillectomy and prosthetic obturator rehabilitation. J Oral Maxillofac Surg. 2013;71(8):1471-8. doi: 10.1016/j. joms.2013.02.002

20. Depprich R, Naujoks C, Lind D, Ommerborn M, Meyer U, Kübler NR, et al. Evaluation of the quality of life of patients with maxillofacial defects after prosthodontic therapy with obturator prostheses. Int J Oral Maxillofac Surg. 2011;40(1):71-9. doi: 10.1016/j.ijom.2010.09.019

21. Seignemartin CP, Miranda ME, Luz JG, Teixeira RG. Understandability of speech predicts quality of life among maxillectomy patients restored with obturator prosthesis. J Oral Maxillofac Surg. 2015;73(10):2040-8. doi: 10.1016/j. joms.2015.04.031
22. Kreeft AM, Krap M, Wismeijer D, Speksnijder CM, Smeele LE, Bosch SD, et al. Oral function after maxillectomy and reconstruction with an obturator. Int J Oral Maxillofac Surg. 2012;41(11):1387-92. doi: 10.1016/j.ijom.2012.07.014

23. Balu K. An innovative three part prosthetic rehabilitation of class-1v facial defect. J Indian Prosthodont Soc. 2013;13(4):6216. doi: 10.1007/s13191-013-0253-y

24. Singh M, Bhushan A, Kumar N, Chand S. Obturator prosthesis for hemimaxillectomy patients. Natl J Maxillofac Surg. 2013;4(1):117-120. 